\title{
ANALISIS PENDAPATAN PETANI PEMASOK SAYURAN KOMERSIAL DI PASAR TRADISIONAL
}

\author{
TD. Soka ${ }^{1}$, A. Yoesdiarti ${ }^{1}$, H. Miftah ${ }^{1 \mathrm{a}}$, \\ ${ }^{1}$ Program Studi Agribisnis, Fakultas Pertanian, Universitas Djuanda Bogor \\ Jl. Tol Ciawi No. 1, Kotak Pos 35 Ciawi, Bogor 16720. \\ ${ }^{a}$ Korespondensi: Himmatul Miftah, E-mail: himmatul.miftah@unida.ac.id
}

\begin{abstract}
This study aims to determine the income and cost structure comparison between commodities of spinach, potatoes, tomatoes and shallots in farmers who supply commodities to traditional markets in the city of Bogor. The selection of farmer respondents was obtained by using snowball sampling, starting from the vegetable retailer at Jambu Dua Traditional Market and Bogor Market. The research was conducted in Bogor Regency, Sukabumi Regency, Bandung Regency (Pangalengan), and Brebes. Research method used was farming income analysis. The results showed that in the area of 0.83 Ha for 6 months, obtained R / C Ratio of spinach 1.09 , tomatoes 1.16 , potatoes 2.36 and red onions 1.39 . All commodities have a proportion of variable costs greater than fixed costs. In potatoes and tomatoes, variable costs take a proportion of costs in excess of $80 \%$. Potatoes and onions have a high proportion of seed costs among other commodities. The highest cost proportion in tomatoes is in manure, while in spinach and onions, the highest cost is found in labor.
\end{abstract}

Keywords: Traditional Markets, Snowball Sampling, Supply Commodities

\begin{abstract}
ABSTRAK
Penelitian ini bertujuan untuk mengetahui pendapatan dan perbandingan struktur biaya antara komoditas bayam, kentang, tomat dan bawang merah pada petani yang memasok komoditas ke pasar tradisional di Kota Bogor. Pemilihan responden petani diperoleh dengan menggunakan snowball sampling dari mulai pelapak sayur di Pasar Tradisional Jambu Dua dan Pasar Bogor. Penelitian dilakukan di Kabupaten Bogor, Kabupaten Sukabumi, Kabupaten Bandung (pangalengan), dan Brebes. Metode penelitian dengan analisis pendapatan usahatani. Hasil menunjukkan bahwa dalam luasan 0,83 Ha selama 6 bulan, diperoleh R/C Ratio bayam 1,09, tomat 1,16, kentang 2,36 dan bawang merah 1,39. Seluruh komoditas memiliki proporsi biaya variabel yang lebih besar dibandingkan biaya tetap. Pada kentang dan tomat, biaya variabel mengambil proporsi biaya lebih dari $80 \%$. Kentang dan bawang memiliki proporsi biaya benih yang paling tinggi diantara komoditas lainnya. Proporsi biaya tertinggi pada tomat terdapat pada pupuk kandang, sementara pada bayam dan bawang, biaya tertinggi terdapat pada tenaga kerja.
\end{abstract}

Kata kunci : Pasar Tradisonal, Snowball Sampling, Pemasok Sayuran 


\section{PENDAHULUAN}

Hortikultura merupakan salah satu sub sektor pertanian yang berperan penting dalam kontribusinya untuk pendapatan nasional. Menurut Direktorat Jenderal Hortikultura 2015, laju pertumbuhan volume ekspor hortikultura menunjukkan nilai positif yaitu sebesar $2,69 \%$ per tahun. Produksi sayuran tahun 2014 meningkat 3,12\% dibandingkan produksi tahun 2013 menjadi sebesar 11.918.571 ton. Data BPS (2014) menunjukkan bahwa sayuran yang memberikan kontribusi produksi terbesar terhadap total produksi sayuran di Indonesia diantaranya adalah $\mathrm{kol} / \mathrm{kubis}$ $(12,05 \%)$, kentang $(11,31 \%)$, bawang merah $(10,35 \%)$, cabai besar $(9,02 \%)$, dan tomat $(7,69 \%)$.

Komoditas hortikultura ini juga mempunyai nilai ekonomi yang tinggi karena dapat menjadi sumber pendapatan bagi masyarakat dan petani karena memiliki keunggulan berupa nilai jual yang tinggi, keragaman jenis, ketersediaan sumberdaya lahan dan teknologi, serta potensi serapan pasar di dalam negeri dan internasional yang terus meningkat. Bahkan sayuran saat ini telah mampu memasok kebutuhan konsumen dalam negeri melalui pasar tradisional dan pasar modern (Dirjen Hortikultura, 2013).

Kota Bogor sebagai salah satu kota yang padat penduduk diperkirakan memiliki permintaan sayuran yang meningkat seiring pertumbuhan penduduk, terutama pada sayuran komersial seperti bayam, tomat, kentang, dan bawang merah. Pasokan sayuran ke Kota Bogor berasal dari berbagai daerah sentra produksi. Penelitian ini bertujuan mengetahui perbandingan pendapatan petani pemasok sayuran komersial ke Kota Bogor dan menganalisis struktur biaya diantara petani pada komoditas bayam, tomat, kentang dan bawang merah.

\section{BAHAN DAN METODE}

Penentuan lokasi asal penelitian dilakukan di pasar tradisional Pasar Bogor dan Pasar Warung Jambu. Pengambilan data primer dilakukan dari bulan Maret Oktober 2017. Penelusuran sampel sampai ke tingkat petani dilakukan dengan metode snowball sampling. Komoditas sayuran yang diteliti bayam, tomat, kentang, dan bawang merah. Penelitian dilakukan di Kabupaten Bogor, Kabupaten Sukabumi, Kabupaten Bandung (pangalengan), dan Brebes sebagai asal daerah petani pemasok.

Pengambilan responden dalam penelitian ini dilakukan dengan metode snowball sampling. Metode snowball sampling adalah teknik penentuan sampel yang mula-mula kecil kemudian akan menjadi besar. Sampel petani diperoleh dengan penelusuran mulai dari pedagang lapak, pedagang pengumpul sampai akhirnya ke petani bayam, tomat, kentang, dan bawang merah. Jumlah responden untuk petani bayam diperoleh sejumlah 10 orang, tomat 10 orang, kentang 5 orang dan bawang merah 10 orang.

Analisis yang digunakan adalah analisis deskriptif dan analisis pendapatan usahatani. Analisis deskriptif digunakan untuk mengolah data karakteristik responden.

\section{HASIL DAN PEMBAHASAN}

Petani responden bayam yang memasok ke Pasar Bogor dan Pasar Warung Jambu (pengecer lapak) berasal dari Kabupaten Bogor yaitu 5 orang petani responden di Semplak dan 5 orang petani di Ciampea. Petani tomat yang menjadi responden pada penelitian ini yaitu petani yang berasal dari Sukabumi dan Bogor. Petani responden pada penelitian ini ini berasal dari Pangalengan-Bandung Jawa Barat yang membudidayakan kentang jenis granola. Petani yang menjadi responden pada penelitian ini adalah petani yang berasal dari Brebes yaitu sebanyak 10 orang petani.

\section{Karakteristik Responden}

Responden dalam penelitian ini adalah petani yang mengusahakan sayuran komersial (Bawang merah, Bayam, 
Kentang, dan Tomat). Beberapa karakteristik petani yang dianggap penting yaitu meliputi umur, jenis kelamin, tingkat pendidikan, pengalaman bertani, luas lahan, kepemilikan lahan, dan jumlah tanggungan keluarga. Umur petani yang dijadikan responden pada penelitian ini sangat beragam. Adapun pengelompokkan umur petani dapat dilihat pada Tabel 1 .

Tabel 1 Karakteristik Responden Komoditas Bayam, Tomat, Kentang dan Bawang merah Berdasarkan Usia

\begin{tabular}{ccccc}
\hline Kelompok & Bayam & Tomat & Kentang & Bawang \\
\cline { 2 - 5 } Umur & $(\%)$ & $(\%)$ & $(\%)$ & $(\%)$ \\
\hline$<30$ & 0 & 30 & 0 & 0 \\
$30-40$ & 10 & 60 & 0 & 10 \\
$41-50$ & 20 & 0 & 80 & 50 \\
$51-60$ & 50 & 0 & 0 & 30 \\
$>60$ & 20 & 10 & 20 & 10 \\
\hline Jumlah & 100 & 100 & 100 & 100 \\
\hline
\end{tabular}

Berdasarkan Tabel 1, presentase terbesar petani pada usia kisaran $51-60$ tahun dengan presentase $50 \%$, responden komoditas tomat berkisar antara $30-40$ tahun dengan presentase $60 \%$, responden komoditas kentang sebesar $80 \%$ berada pada kisaran umur 41 - 50 tahun dan responden bawang merah berkisar pada umur 41 - 50 tahun sebesar 50\%. Pada komoditas tomat, kentang dan bawang merah, responden masih dalam masa usia produktif dalam melakukan sebuah pekerjaan. Petani pada usia muda sudah banyak yang ingin memproduksi komoditas-komoditas pertanian khususnya hortikultura tomat, kentang dan bawang merah. Berbeda dengan responden komoditas bayam, petani yang mengusahakan komoditas bayam berada pada kisaran usia yang sudah memasuki usia kurang produktif.

Responden pada usahatani komoditas bayam, tomat, kentang dan bawang merah dilakukan oleh mayoritas kaum laki-laki dengan prsentase sebesar $100 \%$. Hal ini dikarenakan kaum perempuan lebih banyak menjalankan pekerjaan rumah tangga atau hanya sekedar membantu dalam menjalankan usahatani komoditas bayam, tomat, kentang dan bawang merah.

Tingkat pendidikan yang diperoleh petani akan membantu petani dalam menjalankan usahataninya. Tingkat pendidikan petani yang berbeda dan sebagian besar mayoritas petani pada komoditas bayam, tomat, kentang dan bawang merah menyelesaikan pendidikan pada jenjang pendidikan Sekolah Dasar (SD). Pada responden komoditas bayam dan tomat sebesar $60 \%$ yaitu sebanyak 6 responden dari total 10 responden, responden komoditas kentang sebesar $40 \%$ yaitu sebanyak 2 responden dari total 5 orang responden dan responden komoditas bawang erah sebanyak $60 \%$ yaitu sebanyak 6 responden. Dengan demikian, responden petani yang pernah menempuh pendidikan formal telah mengenal tulisan dan angka sehingga dapat membaca dan berhitung untuk membantu dalam menjalankan usahataninya. Adapun tingkat pendidikan yang telah ditempuh responden petani bayam, tomat, kentang dan bawang merah dapat dilihat pada Tabel 2. 
Tabel 2 Karakteristik Responden Komoditas Bayam, Tomat, Kentang dan Bawang Merah Berdasarkan Tingkat Pendidikan, 2017.

\begin{tabular}{lcccc}
\hline Tingkat & Bayam & Tomat & Kentang & Bawang \\
\cline { 2 - 5 } Pendidikan & $(\%)$ & $(\%)$ & $(\%)$ & $(\%)$ \\
\hline Tidak Tamat SD & 20 & 0 & 20 & 30 \\
Tamat SD & 60 & 60 & 40 & 60 \\
Tamat SMP & 0 & 10 & 20 & 10 \\
Tamat SMA & 20 & 30 & 20 & 0 \\
Perguruan Tinggi & 0 & & 0 & 0 \\
\hline Jumlah & 100 & 100 & 100 & 100 \\
\hline
\end{tabular}

Pengalaman bertani menunjukan seberapa lama petani menjalankan usahataninya. Pengalaman petani sangat berpengaruh terhadap keterampilan dalam menjalankan aktivitas bertaninya serta pemahaman tentang komoditas yang akan dijadikan usahataninya. Pengalaman petani dalam bertani dapat dilihat pada Tabel 3 .

Tabel 3. Karakteristik Responden Berdasarkan Pengalaman Bertani Sayuran Komersial di Beberapa Daerah, 2017

\begin{tabular}{lcccc}
\hline Pengalaman & Bayam & Tomat & Kentang & Bawang \\
\cline { 2 - 5 } Usahatani (Th) & $(\%)$ & $(\%)$ & $(\%)$ & $(\%)$ \\
\hline$<1$ & 0 & 10 & 0 & 0 \\
$1-10$ & 50 & 60 & 20 & 10 \\
$11-20$ & 10 & 30 & 40 & 20 \\
$21-30$ & 20 & 0 & 20 & 60 \\
$>30$ & 20 & 0 & 20 & 10 \\
\hline Jumlah & 100 & 100 & 100 & 100 \\
\hline
\end{tabular}

Tabel 3 menunjukkan bahwa petani bayam dan tomat sebagian besar memiliki pengalaman bertani berkisar antara 1 sampai dengan 10 tahun dengan presentase sebesar $50 \%$ dan $60 \%$, lalu untuk responden komoditas kentang berkisar antara 11 sampai dengan 20 tahun sebesar $40 \%$ dan responden komoditas bawang merah berkisar antara 21 sampai dengan 30 tahun sebesar $60 \%$.
Pengalaman bertani yang dimiliki responden komoditas bayam, tomat, kentang dan bawang merah menunjukkan lamanya responden petani berperan aktif dalam usahatani sayuran. Semakin lama pengalaman bertani maka dapat disimpulkan bahwa responden petani sudah memiliki teknik budidaya dalam kegiatan usahatani yang dijalankannya.

Tabel 4. Karakteristik Responden Berdasarkan Luas Lahan, 2017

\begin{tabular}{lcccc}
\hline \multicolumn{1}{c}{$\begin{array}{c}\text { Luas Lahan } \\
(\mathrm{Ha})\end{array}$} & Bayam & Tomat & Kentang & Bawang \\
\cline { 2 - 5 } & $(\%)$ & $(\%)$ & $(\%)$ & $(\%)$ \\
\hline$<0,25$ & 50 & 0 & 20 & 40 \\
$0,25-0,5$ & 20 & 30 & 40 & 10 \\
$0,51-1$ & 20 & 30 & 0 & 10 \\
$>1$ & 10 & 40 & 40 & 40 \\
\hline \multicolumn{1}{c}{ Jumlah } & 100 & 100 & 100 & 100 \\
\hline
\end{tabular}


Berdasarkan Tabel 4, Luas lahan terbesar yang digarap responden petani bayam untuk menjalankan usahataninya yaitu kurang dari 0,25 ha dengan presentase sebesar $50 \%$. Sedangkan pada responden petani komoditas tomat, luas lahan yang digarap oleh responden petani adalah lebih dari 1 ha dengan presentase sebesar 40\%. Luas lahan komoditas kentang yang digarap oleh responden petani $40 \%$ berkisar antara 0,25 sampai dengan 1 ha dan $40 \%$ lebih dari 1 ha, hal ini dikarenakan responden petani kentang sudah memiliki modal yang cukup untuk mengusahakan komoditas kentang yang dijalaninya. Sedangkan pada komoditas bawang merah, luas lahan yang digarap oleh responden petani $40 \%$ kurang dari 0,25 ha dan $40 \%$ lebih dari 1 ha.

\section{Biaya Produksi dan Pendapatan Sayuran Komersial}

Biaya produksi merupakan biaya yang dikeluarkan untuk membeli kebutuhan usahatani seperti benih/bibit, pestisida, pupuk kandang, pupuk kimia, sewa lahan dan upah tenaga kerja. Biaya Usahatani terdiri dari biaya tetap dan biaya variabel. Biaya tetap terdiri dari penyusutan peralatan dan sewa lahan sedangkan biaya variabel atau biaya tidak tetap terdiri dari benih, pupuk kandang, pupuk kimia dan pestisida. Pada Tabel 5 menunjukan rata-rata penggunaan input usahatani kentang, bayam, tomat, dan bawang merah. Penggunaan input pada masing-masing usahatani sayuran berbedabeda sehingga biaya yang dikeluarkan juga berbeda.

Tabel 5 Rata-rata Biaya Produksi dan Pendapatan pada Usahatani Bayam, Tomat, Kentang, dan Bawang Merah Per 6 Bulan tanam Per 0,81 Ha.

\begin{tabular}{lcccc}
\hline \multicolumn{1}{c}{ Uraian } & Bayam & Tomat & Kentang & Bawang \\
\hline Biaya Variabel & & & & \\
Benih & 2.946 .000 & 3.162 .000 & 45.727 .200 & 67.350 .000 \\
Pupuk Urea & 3.636 .000 & 2.710 .000 & 4.000 .000 & 1.674 .000 \\
Pupuk TSP & 1.671 .000 & 1.913 .334 & 18.066 .668 & 1.653 .750 \\
Pupuk NPK & 0 & 0 & 6.450 .000 & 5.559 .600 \\
Pupuk KCL & 1.785 .000 & 3.311 .428 & 22.000 & 2.309 .100 \\
Pupuk kandang & 1261806 & 24.233 .334 & 12.600 .000 & 0 \\
Pestisida & 3.777 .000 & 7.202 .000 & 9.661 .000 & 18.578 .334 \\
Mulsa & 0 & 10.047 .000 & 7.060 .000 & 0 \\
Turus & 0 & 16.090 .000 & 2.900 .000 & 0 \\
Karung & 0 & 0 & 1.560 .000 & 0 \\
Total Biaya Variabel & 15.076 .806 & 68.669 .096 & 108.046 .868 & 97.124 .784 \\
Biaya Tetap & & & & \\
Tenaga kerja & 6.057 .750 & 8.474 .000 & 5.050 .000 & 74.287 .500 \\
Penyusutan & 764.376 & 1.445 .998 & 5.796 .260 & 525.429 \\
Sewa lahan & 1.864 .284 & 1.950 .000 & 2.970 .000 & 2.925 .000 \\
Total Biaya Tetap & 8.686 .410 & 11.869 .998 & 13.816 .260 & 77.737 .929 \\
Total Biaya & 23.763 .216 & 80.539 .094 & 121.863 .128 & 174.862 .713 \\
Penerimaan & 25.920 .000 & 93.300 .000 & 288.000 .000 & 242.250 .000 \\
Pendapatan & 2.156 .784 & 12.760 .906 & 166.136 .872 & 164.512 .071 \\
R/C & 1,09 & 1,16 & 2,36 & 1,39 \\
Keterangan & $6 x$ produksi & $2 x$ produksi & $2 x$ produksi & $3 \times$ produksi \\
\hline
\end{tabular}


Biaya variabel yang dikeluarkan untuk usahatani bayam yaitu sebesar Rp. 15.076.806 dan biaya tetap yang dikeluarkan sebesar Rp. 8.686.410 dalam satu periode produksi ( 6 bulan) dengan penerimaan total sebesar Rp. 25.920.000,sehingga pendapatan yang diterima oleh petani bayam yaitu sebesar 2.156.784,dengan nilai $\mathrm{R} / \mathrm{C}$ sebesar 1,09 yang artinya setiap Rp. 1 modal yang dikeluarkan pada usahatani bayam maka menghasilkan penerimaan sebesar Rp. 1,09 dalam satu periode produksi. Hal ini menunjukkan bahwa usahatani bayam memberikan keuntungan kepada petani.

$$
\text { Penggunaan biaya yang }
$$

dikeluarkan untuk usahatani tomat yaitu kebutuhan benih/bibit, biaya pupuk kandang, pupuk kimia, pestisida, mulsa dan lain-lain. Biaya total yang dikeluarkan untuk kegiatan ushaatani tomat yaitu sebesar Rp. 80.539.094,- dalam 2 kali produksi (6 bulan) dengan penerimaan sebesar Rp. 93.300.000,- pendapatan yang diterima sebesar Rp. 12.760.906,- dengan nilai $\mathrm{R} / \mathrm{C}$ sebesar $\mathrm{Rp} 1,16$ yang artinya setiap Rp 1 modal yang dikeluarkan akan menghasilkan penerimaan sebesar Rp 1,16. Hal ini menjelaskan bahwa usatani tomat masih memberikan keuntungan dan layak untuk diusahakan.

Pada kegiatan usahatani kentang biaya total yang harus dikeluarkan selama 2 kali produksi (6 bulan) yaitu sebesar $R p$ 121.863.128,- dengan penerimaan yang diterima sebesar Rp. 288.000.000,- dan pendapatan yang diterima sebesar $\mathrm{Rp}$. 166.36.872,- dengan nilai R/C sebesar Rp 2,36 yang artinya setiap Rp. 1 modal yang dikeluarkan maka menghasilkan penerimaan sebesar Rp. 2,36. Hal ini menjelaskan bahwa kegiatan usahatani kentang sangat layak untuk diusahakan. Perbandingan struktur biaya pada keempat jenis komoditas dapat dilihat pada Tabel 5.

Tabel 5. Persentase Biaya Produksi pada Usahatani Bayam, Tomat, Kentang, dan Bawang Merah Per 6 Bulan tanam Per 0,81 Ha.

\begin{tabular}{lcccr}
\hline Uraian & Bayam & Tomat & Kentang & Bawang \\
\hline Biaya Variabel & & & & \\
Benih & $12,40 \%$ & $3,93 \%$ & $37,52 \%$ & $38,52 \%$ \\
Pupuk Urea & $15,30 \%$ & $3,36 \%$ & $3,28 \%$ & $0,96 \%$ \\
Pupuk TSP & $7,03 \%$ & $2,38 \%$ & $14,83 \%$ & $0,95 \%$ \\
Pupuk NPK & $0,00 \%$ & $0,00 \%$ & $5,29 \%$ & $3,18 \%$ \\
Pupuk KCL & $7,51 \%$ & $4,11 \%$ & $0,02 \%$ & $1,32 \%$ \\
Pupuk kandang & $5,31 \%$ & $30,09 \%$ & $10,34 \%$ & $0,00 \%$ \\
Pestisida & $15,89 \%$ & $8,94 \%$ & $7,93 \%$ & $10,62 \%$ \\
Mulsa & $0,00 \%$ & $12,47 \%$ & $5,79 \%$ & $0,00 \%$ \\
Turus & $0,00 \%$ & $19,98 \%$ & $2,38 \%$ & $0,00 \%$ \\
Karung & $0,00 \%$ & $0,00 \%$ & $1,28 \%$ & $0,00 \%$ \\
Total Biaya Variabel & $\mathbf{6 3 , 4 5 \%}$ & $\mathbf{8 5 , 2 6 \%}$ & $\mathbf{8 8 , 6 6 \%}$ & $\mathbf{5 5 , 5 4 \%}$ \\
Biaya Tetap & & & & \\
Tenaga kerja & $25,49 \%$ & $10,52 \%$ & $4,14 \%$ & $42,48 \%$ \\
Penyusutan & $3,22 \%$ & $1,80 \%$ & $4,76 \%$ & $0,30 \%$ \\
Sewa lahan & $7,85 \%$ & $2,42 \%$ & $2,44 \%$ & $1,67 \%$ \\
Total Biaya Tetap & $\mathbf{3 6 , 5 5 \%}$ & $\mathbf{1 4 , 7 4 \%}$ & $\mathbf{1 1 , 3 4 \%}$ & $\mathbf{4 4 , 4 6 \%}$ \\
\hline
\end{tabular}

Penggunaan biaya variabel untuk kegiatan usahatani bawang merah sebesar Rp. 97.124.784,- dan biaya tetap sebesar Rp. 77.737 .929 selama 3 kali produksi (6 bulan) dengan penerimaan total yang diterima sebesar Rp. 242.250.000,- dan pendapatan yang didapat sebesar Rp. 164.512.071 sehingga menghasilkan nilai R/C sebesar Rp. 1,39 artinya setiap Rp. 1 modal yang dikeluarkan maka 
menghasilkan penerimaan sebesar $\mathrm{Rp}$. 1,39, sehingga usahatani bawang merah layak untuk diusahakan. Seluruh komoditas memiliki proporsi biaya variabel yang lebih besar dibandingkan biaya tetap. Pada kentang dan tomat, biaya variabel mengambil proporsi biaya lebih dari $80 \%$. Kentang dan bawang memiliki proporsi biaya benih yang cukup tinggi diantara komoditas lainnya. Proporsi biaya tertinggi pada tomat terdapat pada pupuk kandang, sementara pada bayam dan bawang, biaya tertinggi terdapat pada tenaga kerja.

\section{KESIMPULAN DAN SARAN}

\section{Kesimpulan}

Karakter responden diketahui mayoritas Hasil menunjukkan bahwa dalam luasan 0,83 Ha selama 6 bulan, seluruh pendapatan petani dinilai layak karena memiliki R/C Ratio lebih dari 1. $\mathrm{R} / \mathrm{C}$ ratio tertinggi diperoleh petani komoditas kentang. Sementara R/C Ratio bayam 1,09, tomat 1,16 , dan bawang merah 1,39. Seluruh komoditas memiliki proporsi biaya variabel yang lebih besar dibandingkan biaya tetap. Pada kentang dan tomat, biaya variabel mengambil proporsi biaya lebih dari $80 \%$. Kentang dan bawang memiliki proporsi biaya benih yang cukup tinggi diantara komoditas lainnya. Proporsi biaya tertinggi pada tomat terdapat pada pupuk kandang, sementara pada bayam dan bawang, biaya tertinggi terdapat pada tenaga kerja.

\section{Implikasi Kebijakan}

$\mathrm{R} / \mathrm{C}$ ratio pada sayuran bayam dan tomat relatif kecil, sehingga diperlukan langkah-langkah untuk efisiensi biaya tenaga kerja pada bayam, dan efisiensi biaya pupuk kandang pada tomat. Sebaiknya dilakukan analisis lebih dalam terkait budidaya pada sayuran komersial sehingga dapat meningkatkan efisiensi biaya.

\section{Daftar Pustaka}

Asmarantaka RW. 2012. Pemasaran Agribisnis (Agrimarketing). Bogor (ID): Departemen Agribisnis FEMIPB.

Badan Pusat Statistika. 2014. Produksi Sayuran Tahun 2013-2014. Http://www.bps.go.id. Diaskes 30 April 2017

Badan Pusat Statistika. 2016. Statistik Daerah Kota Bogor 2016. Http://www.bps.go.id. Diaskes 08 Mei 2017

Badan Pusat Statistik Jawa Barat. 2016. Data Pertumbuhan Penduduk Jawa Barat.

Badan Pusat Statistik Jawa Barat. 2015. Data Produksi Pertanian Tahun 2014-2015. Http://www.bps.go.id. Diakses 01 Mei 2017

Direktorat Jenderal Hortikultura. 2015. Perkembangan Volume dan Nilai Ekspor Impor Komoditas Hortikultura Tahun 2010-2014.

Kementerian Pertanian. 2015. Statistik Produksi Hortikultura Tahun 2014. Direktorat Jenderal Hortikultra, Kementrian Pertanian. Jakarta.

Kementerian Pertanian. 2015. Perkembangan Konsumsi Rumah Tangga per Kapita di Indonesia 2011-2015. Kementerian Pertanian RI. www.pertanian.go.id. Diaskes 30 April 2017

Kementrian Pertanian. 2015. Rencana Strategis Kementrian Pertanian 2010 - 2014. Kementrian Pertanian. Jakarta.

Mehmood, et al. 2011. Benefit Cost Ratio Analysis Of Organic And Inorganic Rice Crop Production; Evidence From District Sheikhupura In Punjab Pakistan. Pakistan Journal of Science (Vol. 63 No. 3 September, 2011)

Setyadi, S. R. 1989. Dasar-dasar Hortikultura. Jurusan Budidaya Pertanian. Institut Pertanian Bogor. Bogor 